\title{
Emoção e Masculinidade no Universo do Futebol no Brasil*
}

\author{
Fábio Daniel da Silva Rios** \\ Maria Claudia Pereira Coelho***
}

\section{Resumo}

Este artigo tem por objetivo discutir a relação entre emoções $e$ masculinidade no universo do futebol brasileiro, com foco no descontrole emocional masculino presente nas experiências de torcedores. A metodologia utilizada foi a entrevista em profundidade, realizada com dez torcedores de clubes do Rio de Janeiro. Os resultados sugerem que o predomínio desse padrão emotivo aponta para a articulação da masculinidade, no contexto do futebol, a uma sensibilidade definida no Ocidente moderno como um atributo feminino, problematizando assim a associação entre feminino, descontrole emocional e perigo.

Palavras-chave: Emoção, Masculinidade, Futebol.

* Recebido em 03 de abril de 2019, aceito em 24 de maio de 2019.

** Doutor em Ciências Sociais pela UERJ, Rio de Janeiro, RJ, Brasil. fabiodanielsr@gmail.com / https://orcid.org/0000-0002-0739-7149

*** Professora Titular do Departamento de Antropologia do Instituto de Ciências Sociais da UERJ, Rio de Janeiro, RJ, Brasil. mccoelho@bighost.com.br / https://orcid.org/0000-0003$\underline{3885-5429}$ 
Emotion and Masculinity in Brazilian Soccer World

\begin{abstract}
This paper discusses the relation between emotions and masculinity in Brazilian soccer world. Its focus is on lack of emotional control among men as described in fan experiences. Ten in-depth interviews were conducted with fans of Rio de Janeiro soccer teams. The results suggest that the prevalence of this emotional pattern points to an articulation of masculinity, in the context of soccer, to a sensibility understood in contemporary Western societies as a female attribute, therefore problematizing the association between the feminine, a lack of emotional control and danger.
\end{abstract}

Keywords: Emotion, Masculinity, Soccer. 


\section{Introdução}

Este artigo tem por objetivo discutir a relação entre emoções e masculinidade no universo do futebol brasileiro ${ }^{1}$. Seu foco analítico é o descontrole emocional presente em relatos de experiências de torcer, obtidas junto a torcedores de clubes cariocas. A proposta insere-se teoricamente na área de investigação da Antropologia das Emoções, procurando contribuir, por meio desse caso etnográfico, para problematizar um tema central da literatura antropológica sobre as emoções: a estreita associação entre a feminilidade e o descontrole emocional. Essa associação tem por consequência a desvalorização tanto da feminilidade quanto das emoções, entendidas como locus do perigo e da vulnerabilidade, implicando assim a valorização da razão e do controle associados à masculinidade.

$\mathrm{Na}$ introdução ao dossiê "Masculinities in times of uncertainty and change", Piscitelli e Simoni (2015) revisitam o conceito de "masculinidades hegemônicas", argumentando em favor da permanência da sua relevância para os estudos de gênero. Entre suas razões, estão o desafio a qualquer universalização e a contribuição potencial das análises comparativas para a desnaturalização das categorias utilizadas pelos próprios etnógrafos.

Estudos sobre gênero e emoção parecem, assim, se encontrar em pontos nodais das démarches de suas respectivas construções enquanto áreas autônomas de investigação. Em comum, a noção de "construção cultural", que fez também seu trabalho na Antropologia das Emoções, permitindo esse duplo movimento: desconfiar da universalização das categorias utilizadas para se pensar as emoções (como no trabalho teórico realizado pelas vertentes relativista $e$ historicista, tal como discutido por AbuLughod e Lutz [1990]) e, num "efeito bumerangue" dessa

1 O artigo é uma versão desenvolvida de resultados apresentados na dissertação de mestrado de autoria de Fábio Daniel Rios (2014), defendida no Programa de Pós-Graduação em Ciências Sociais (PPCIS) da UERJ sob orientação de Maria Claudia Coelho. 
desconfiança, desnaturalizar a "etnopsicologia euroamericana", colocando assim sob escrutínio a gramática que opõe emoção/descontrole/feminino a razão/controle/masculino.

A metodologia utilizada foi a entrevista em profundidade. Foram realizadas 10 entrevistas, com torcedores dos principais clubes do Rio de Janeiro: Botafogo (2), Flamengo (3), Fluminense (3) e Vasco (2). Por se tratar de uma pesquisa sobre a relação entre emoção e masculinidade, foram entrevistados apenas torcedores do sexo masculino, que tivessem o hábito de acompanhar seus clubes no dia a dia. Quanto ao perfil socioeconômico, os entrevistados tinham entre 24 e 63 anos e pertenciam majoritariamente à classe média, com rendas familiares que variavam entre $R \$ 3.000$ e $R \$ 15.000$. A maioria possuía formação escolar até o nível superior, apresentando diferentes ocupações (estudante, comerciante, jornalista, economista, professor universitário, funcionário público, auxiliar administrativo, recrutador, motorista e militar) e residindo em diferentes bairros $e$ regiões da cidade do Rio de Janeiro (Bangu, Barra da Tijuca, Pechincha, Méier, Engenho Novo, Vila Isabel, São Cristóvão, Jardim Botânico e Copacabana).

Nas entrevistas, os torcedores foram questionados sobre a importância da relação afetiva mantida com seu "clube do coração" e sobre o sentimento que teriam por ele, abarcando o efeito dessa relação sobre seu comportamento e suas emoções para além dos dias de jogos, relatos de "loucuras" e "sacrifícios" realizados em nome do clube, episódios de choro, e ainda, memórias marcantes vivenciadas em suas trajetórias como torcedores.

O texto está estruturado em três partes. A primeira apresenta os conceitos fundadores do campo da Antropologia das Emoções nos Estados Unidos, na década de 1980, com foco na articulação entre gênero e (des)controle emocional. A seguir, expomos algumas explorações existentes na literatura brasileira da área sobre a dimensão emocional da experiência esportiva. A terceira parte examina os discursos dos entrevistados sobre seus sentimentos em relação ao "clube do coração", nos quais se 
destacam o amor, a paixão e a fidelidade. Ao caracterizarem a importância da relação mantida com seus clubes, os entrevistados relataram diversos episódios marcados pelo "excesso" e pelo "descontrole", analisados aqui à luz de sua relação com o ideário do amor-paixão e do amor romântico em contraposição ao "fanatismo". O lugar do choro como expressão desse descontrole e suas associações a sentimentos específicos - raiva, alegria ou tristeza - também é examinado. Nas considerações finais, discutimos a forma como o predomínio desse padrão emotivo aponta para a articulação da masculinidade, no contexto do futebol, a uma sensibilidade definida no Ocidente moderno como um atributo feminino, problematizando assim a associação entre feminino, descontrole emocional e perigo que, de acordo com Lutz (1988), organizaria a concepção ocidental da vida emocional.

\section{As emoções como objeto das ciências sociais: matrizes teóricas e conceitos fundadores}

A Antropologia das Emoções começa a se constituir como uma área autônoma de investigação nos Estados Unidos na década de 1980, quando vários trabalhos seminais são publicados, destacando-se: a) a discussão de Michelle Rosaldo (1984) sobre as implicações da antropologia interpretativista de Clifford Geertz para a construção do self e dos sentimentos como objetos de investigação antropológica; b) a etnografia de Lila Abu-Lughod (1986) sobre a honra, o amor e o recato em uma aldeia beduína no Egito; c) a revisão bibliográfica elaborada por Catherine Lutz e Geoffrey White (1986) sobre as diversas correntes de análise das emoções nas Ciências Humanas; e d) a etnografia de Catherine Lutz (1988) sobre os Ilongot, com destaque para o delineamento, por contraste, da visão "euroamericana" da vida emocional. Para os propósitos deste artigo, interessa expor com mais detalhamento a análise de Catherine Lutz sobre a "etnopsicologia" euroamericana.

"Etnopsicologia" é o termo utilizado pela autora para designar o modo como um grupo entende as experiências 
emocionais, seja a emoção em si, sejam emoções específicas. A etnopsicologia euroamericana seria organizada em torno de duas oposições: emoção-razão e emoção-distanciamento.

Esse esquema se articula à diferenciação entre os gêneros, estipulando diferentes padrões emocionais para homens $e$ mulheres. Assim, na oposição emoção-razão, as emoções são concebidas como um fenômeno tipicamente feminino, sendo associadas às noções de irracionalidade $e$ descontrole $e$ constituindo, por isso, o polo negativo da oposição. Os homens, por sua vez, seriam essencialmente racionais, com o controle emotivo erigido como norma de conduta fundamental para a constituição cultural da masculinidade hegemônica e fazendo do masculino o polo positivo da oposição.

$\mathrm{Na}$ segunda oposição, as valorações são invertidas. A emoção continua sendo o polo associado às mulheres, porém agora dotando a feminilidade da valência positiva, uma vez que emoção significa, aqui, a capacidade da empatia, de se identificar $e$ se compadecer do sofrimento alheio. Seu oposto é o distanciamento, a racionalidade pura que se transmuta em indiferença ou "frieza" emocional, atributo da masculinidade que ocupa agora o polo da valência negativa.

Para Lutz, essas oposições organizariam toda a percepção da vida emocional no Ocidente moderno, aparecendo sob diversas roupagens em todas as áreas da vida - nas várias modalidades artísticas, na ciência, na política etc. As formas do lazer, das brincadeiras, dos jogos e dos esportes não são, evidentemente, refratárias a essa divisão do trabalho emocional. É o que veremos a seguir.

Emoções, gênero e controle no universo esportivo

No livro Em busca da excitação (1992), Elias e Dunning desenvolvem uma abordagem pioneira sobre a relação entre emoção e esporte, a partir da teoria do "processo civilizador". Os esportes modernos teriam se originado da civilização de jogos populares medievais, marcados por níveis muito elevados de 
violência e desorganização. Após um longo período de perseguição pelas autoridades reais e eclesiásticas, esses jogos foram incorporados e adaptados por instituições de ensino frequentadas pelos filhos da elite burguesa e aristocrática, ganhando regras que os tornaram mais organizados e menos violentos - conformando-se, assim, ao ethos moderno. No lugar da livre expressão do comportamento agressivo, a excitação passou a ser produzida a partir das limitações impostas pelas regras, tornando o alcance dos objetivos mais difícil e desafiador. Segundo os autores, os esportes modernos se constituem, então, como "válvulas de escape", que permitem o necessário extravasamento das pulsões, de modo seguro, numa sociedade caracterizada pelo autocontrole como norma de conduta.

Em outro trabalho sobre a relação entre emoção e esporte, Luiz Fernando Rojo (2011) analisa a articulação entre gênero $e$ emoção no hipismo, a partir de uma comparação entre as cidades do Rio de Janeiro e de Montevidéu. Esse esporte consiste na única modalidade olímpica a permitir a participação de homens $e$ mulheres nas mesmas competições, sendo marcado por um discurso igualitarista de gênero ${ }^{2}$. Embora não haja uma separação formal, observa-se, contudo, uma participação maior de homens nas provas de salto e de mulheres nas provas de adestramento.

Segundo os entrevistados, por serem mais emotivas, sensiveis $e$ intuitivas, as mulheres teriam maior facilidade para lidar com os cavalos, o que as tornaria mais aptas que os homens

\footnotetext{
2 Essa mesma representação igualitária do hipismo foi o ponto de partida para uma série de trabalhos desenvolvidos por Miriam Adelman (2011) sobre a relação entre gênero e esporte - mais precisamente, entre feminilidade e esportes equestres. Partindo da compreensão do meio esportivo, como um todo, e dos esportes equestres, em especial, como histórica e fortemente associados à homossociabilidade masculina, Adelman abordou os limites $e$ as possibilidades de transgressão presentes na atuação das mulheres como amazonas em três modalidades: hipismo clássico, turfe e rodeio. A despeito das particularidades de cada segmento, a autora destaca a produção de identidades e subjetividades femininas que enfatizam noções de coragem e determinação, subvertendo assim esquemas tradicionais de gênero, tendo em vista a recorrente associação cultural desses elementos à masculinidade.
} 
para as provas de adestramento. As provas de salto, por outro lado, exigiriam coragem e um maior controle das emoções, tornando os homens mais habilitados para essas competições. Rojo destaca, ainda, que a grande presença de militares no hipismo uruguaio faria com que a relação entre feminilidade $e$ emoção fosse minimizada nas representações sobre o esporte nesse contexto.

Ele conclui que, apesar das representações igualitaristas predominantes no hipismo, as diferenças entre os sexos são reintroduzidas através dos discursos emotivos, que reforçam a emotividade como um atributo feminino, $e$ a racionalidade como uma qualidade masculina, em conformidade com os princípios da "etnopsicologia ocidental" (Lutz, 1988).

Estudos sobre a experiência emocional ligada ao futebol apontam o torcedor como o "locus da emoção" nesse contexto. Nas diversas abordagens sobre o tema, seja da imprensa especializada, do marketing esportivo, ou ainda do meio acadêmico, o torcedor é entendido como aquele que se relaciona com o futebol motivado por um "engajamento emocional" (Damo, 2002). Para os demais integrantes desse universo (dirigentes, jogadores, jornalistas etc.), as emoções também desempenham um papel importante, mas devem ser racionalizadas para o devido cumprimento de suas funções. Assim, o comportamento emotivo é o que singulariza a condição de torcedor no contexto do futebol.

Seguindo essa abordagem, Bandeira (2012) examina os discursos de amor e paixão produzidos pelos torcedores nos estádios de futebol. Além de consistirem no espaço ritual onde ocorrem os confrontos diretos entre as equipes, os estádios são também o lugar onde os sentimentos dos torcedores são vivenciados e manifestados coletivamente, de modo padronizado $e$ segundo regras específicas. Através de cantos, bandeiras, coreografias etc., os torcedores juram amor eterno $e$ fidelidade aos 
clubes, declarando-se capazes de cometer "loucuras" $e$ "sacrifícios" motivados pela paixão que sentem por ele $e^{3}$.

\section{O sentimento pelo clube: amor, paixão $e$ fidelidade}

O roteiro das entrevistas convidava os torcedores a recomporem e narrarem suas trajetórias, enfocando a importância da relação mantida com seu "clube do coração" e o impacto dessa ligação afetiva sobre suas vidas. Em seus discursos, prevaleceram os sentimentos de amor e paixão, como no depoimento abaixo:

Olha só, não especificamente pelo time, mas eu acho que pelo clube, por essa Nação, por ser Flamengo, entendeu? É um espírito de amor, carinho, paixão, entendeu? (...) Ficar agoniado quando perde (...). (Ademir ${ }^{4}$ ).

Nesse relato, é interessante notar a diferença feita entre o "time", que se limitaria a um conjunto passageiro de jogadores, $e$ o "clube", que remeteria a algo maior. O sentimento do entrevistado estaria relacionado à sua identidade como torcedor do Flamengo e ao seu pertencimento a uma "comunidade

3 Ao combinar a intensidade do amor-paixão com a estabilidade do amor romântico, essas manifestações parecem seguir seus ideais, tal como definidos por Giddens (1993) em A Transformação da Intimidade. Para o autor, o amorpaixão seria marcado por um sentido de urgência que o coloca à parte das rotinas da vida cotidiana, com a qual tende a entrar em conflito, pois sua intensidade pode levar os indivíduos a ignorarem suas obrigações habituais, perturbar suas relações pessoais e gerar um "esmagamento do eu", uma inclinação ao radicalismo e à realização de sacrifícios. É, assim, um sentimento que tende a ser visto como perigoso. $\mathrm{O}$ amor romântico, um elemento da modernidade ocidental, apesar de manter algo do encantamento do amorpaixão, seria acompanhado também pelas noções de exclusividade e eternidade, as quais the conferem uma estabilidade ou durabilidade que o credenciam a servir de base para o casamento nesse contexto sócio-histórico. Giddens enfatiza o caráter essencialmente feminilizado do amor romântico, o que estaria relacionado à identificação das mulheres com o âmbito privado, fazendo do mundo dos afetos e da intimidade um território ligado à feminilidade.

${ }^{4}$ Os nomes dos entrevistados foram alterados para preservar suas identidades. 
imaginada de sentimentos" ${ }^{2}$, formada pelos demais torcedores do clube. Em outra passagem, ele volta a definir seu afeto pelo clube como amor: "O Flamengo é assim, é amar ou amar... é amar ou amar, não tem jeito!".

O amor também aparece em outras entrevistas: "Eu acho que é igual a todo torcedor, né? É... Num deixa de ser um amor, né, cara?" (Pedro).

Pedro define sua relação com o Botafogo como amor, que em sua visão seria o sentimento tipicamente devotado por qualquer torcedor ao seu "clube do coração". Nesse tipo de relação, as vitórias e derrotas de um time poderiam afetar as emoções e o humor de seus torcedores. Outro entrevistado recorre ao termo "paixão" para definir seu sentimento pelo clube: "Agora, se tiver que definir em uma palavra, eu diria que é paixão o que eu sinto." (Bernardo).

Jaime foi mais enfático ao definir seu sentimento pelo Fluminense. Foi ele o entrevistado que mais se aproximou do discurso que valoriza os exageros e sacrifícios que caracterizam o amor-paixão. Ele define seu sentimento pelo clube como "uma paixão infindável":

Uma paixão infindável... (...) Trocaria qualquer coisa. Eu trocaria a minha carreira... de qualquer coisa, qualquer carreira que eu tenha, trocaria pra ver o Fluminense sempre campeão, todo dia. Tudo! Trocaria todas as mulheres que eu tive na minha vida... tudo, tudo que você possa... pensa uma coisa, eu trocaria. (...) É incondicional, é uma coisa que num, é... num, num dá pra dizer...

Esse sentimento que "num dá pra dizer" é um mote que ressurge em outras passagens do mesmo relato: "as paixões você não explica (...) você se apaixona e pronto". Essa maneira aparentemente paradoxal de "explicar" o sentimento definindo-o

${ }^{5}$ Elaborado por Anderson (2008) para se referir aos Estados Nacionais, o termo é adaptado por Damo (2002) para se referir aos clubes de futebol. 
como "inexplicável" aparece em diversas outras entrevistas, voltando a ser manifestada por Jaime em outro trecho:

Eu não sei explicar, eu sei que é muito forte, é forte assim de, de minha, meu batimento cardíaco mudar, eu perder os sentidos, eu perder o tônus, eu... eu jogar sapato na televisão e quebrar a televisão em casa, é... ninguém me conhece, só quem me vê... a minha primeira mulher, que é uma amiga que eu tenho até hoje, ela disse que só me conheceu, (...) no dia que ela me viu no Maracanã.

O sentimento pelo clube teria, assim, a marca do indizível. Essa percepção pode ser relacionada ao modo como as emoções são concebidas na cultura ocidental. Segundo Abu-Lughod e Lutz (1990), ao serem definidas como fenômenos naturais, subjetivos e irracionais, as emoções se tornariam refratárias a qualquer forma de teorização ou reflexividade, sendo relacionadas aos planos do corpo, das sensações e da experiência. Essa percepção da vida emocional surge claramente na maneira como o entrevistado procura expor a intensidade de seu sentimento: através de uma descrição dos fortes efeitos que ele exerceria sobre seu corpo e seu comportamento.

Devido à sua natureza supostamente "irracional", as emoções costumam ser entendidas como algo da ordem do incomunicável. São também tomadas como signos da originalidade e espontaneidade da vida interior dos sujeitos, em contraste com a possibilidade de manipulação das formas expressivas ("ela só me conheceu no dia em que me viu no Maracanã"). Assim, é como se os sentimentos só pudessem se tornar conhecidos no plano da experiência, ao serem vivenciados de modo singular por cada indivíduo. As tentativas de expressão das emoções não conseguiriam captar seu real significado $e$ intensidade. Em termos simmelianos, poderíamos dizer que o fluxo da vida nem sempre consegue encontrar abrigo nas formas fixas oferecidas pela cultura (Simmel, 1983). Desse modo, afirmar a incomunicabilidade de um sentimento pode ser entendido como um recurso discursivo para indicar sua originalidade $e$ intensidade. 
Na sequência, o mesmo entrevistado ressalta a importância das emoções vivenciadas através do futebol para outras áreas de sua vida:

Eu aprendi a me apaixonar com o futebol. Quer dizer, se eu hoje sou uma pessoa apaixonada por tudo o que eu faço, eu sou, se eu sou apaixonado pelas mulheres que eu amei, que eu amo, que eu vivi, num é? O futebol me ensinou isso. Porque a minha paixão pelo futebol é anterior. (...) O futebol me fez essa figura apaixonada, eu sou apaixonado por causa do futebol. O futebol me ensinou isso, quer dizer. A primeira coisa que eu me apaixonei, na minha vida, foi pelo futebol. O futebol é devastador pra mim, assim. Devastador, num sentido que eu considero positivo, não no sentido de me fazer mal. Me faz mal... me faz mal. Mas me faz mal, me fazendo bem. (...) Portanto, existencialmente é importante pra mim. Eu espero morrer num estádio de futebol, eu sempre digo isso, com o Fluminense campeão. Primeiro vendo campeão, depois morrendo. Seria melhor do que morrer em cima de uma cama, doente.

O futebol aqui é descrito como capaz de constituir, por meio de um "estilo de sentir", a própria maneira de ser. Essa capacidade é caracterizada como "devastadora", o que aparece, porém, como um aspecto positivo em sua perspectiva. Com esse termo, Jaime se refere aos efeitos do futebol sobre sua vida que considera nocivos, que lhe "fazem mal", mas, ao mesmo tempo, "fazem bem". Ao longo da entrevista, ele relata diversos episódios de mal-estar e desmaios, que seriam decorrentes das fortes emoções vivenciadas através do futebol:

Me lembro, nitidamente, do desmaio que eu tive em 71, Fluminense e Botafogo, a final, gol do Lula. Eu subi pra comemorar e já vi tudo preto, já caí no chão. (...) De lá pra cá, algumas vezes, uma tendência ao desmaio, muitas vezes... em 2008, na final da Libertadores, eu botei meu carro aqui dentro da UERJ, e... saí do Maracanã arrasado com a final da LDU, embora tivéssemos ganho o jogo, não 
ganhamos o, a Libertadores. E me lembro de estar sentado no carro, pra tentar sair da UERJ, e não conseguir até seis horas da manhã, chorando... e minha mulher ligando desesperadamente, "Você não vem pra casa?!", eu digo "Eu não consigo dirigir". Eu chorava sem parar. (...) Mas futebol é muito forte, comigo é muito forte... vai me matar um dia, tenho certeza. Tomara que me mate, prefiro morrer de futebol, do que de qualquer outra coisa.

À maneira de um poeta ultrarromântico, o entrevistado declara sua disposição em viver sua paixão até as últimas consequências. Sob os princípios da ética romântica, somente a vivência plena das emoções pode conferir um verdadeiro sentido à vida (Campbell, 2001). Em outra passagem, essa tendência aparece num episódio em que ele diz ter misturado remédios e bebidas alcoólicas, em virtude de uma "depressão profunda" ocasionada pela derrota de seu time:

O Fluminense, em vez de ser campeão de 2012, perde o jogo pro Atlético-MG, 3 a $2 \ldots$ eu entro numa depressão profunda, viro um litro de vodka, misturo com Rivotril, que é um remédio brabo, que eu... (...) Sou epilético, tenho um quê de epilepsia. E... eu não dou conta de nada, penso que eu vou morrer, assim. Minha mulher chega em casa, fala comigo, eu não respondo. Eu caio no chão da cama, acordo no outro dia... Completamente desvanecido, achando que tinha perdido o título, que tava na mão. (...) Mas o momento muito, muito... um dos momentos mais tristes, assim, foi essa derrota pro Atlético e a LDU, né? As duas vezes. A segunda vez, eu quebrei a televisão com o, com uma sapatada, (...). Foi triste também. Mas o AtléticoMG foi muito ruim, porque foi uma coisa da tensão de perder o jogo, perder o campeonato. E eu... eu pirei com o jogo, eu pirei completamente com o jogo. Enlouqueci.

O entrevistado caracteriza a si mesmo como alguém "emocionalmente conturbado", referindo-se à paixão por seu clube como uma espécie de "loucura" ou "doença" em diversos 
momentos. Em sua entrevista, as emoções aparecem como sinônimos de irracionalidade, excesso e descontrole, em conformidade com a ideologia cultural do Ocidente (Abu-Lughod; Lutz, 1990). Desse modo, elas são concebidas como elementos perigosos, que ameaçam sua saúde e o levam a atitudes extremas. No entanto, isso aparece de modo ambivalente, pois o descontrole emocional assume um sentido positivo ao ser apresentado como evidência da força de seu afeto como torcedor.

Vítor também se considera um torcedor "fanático". Segundo ele, a torcida do Fluminense conta com um "bom número de fanáticos" que vão sempre aos estádios para assistir aos jogos. $\mathrm{O}$ entrevistado inclui a si mesmo nesse grupo:

Eu sou muito, muito, muito fanático pelo Fluminense, eu realmente sou muito fanático. Todas as pessoas que convivem comigo, elas sabem que, assim, isso influencia muito na minha vida. (...) Minha namorada é Fluminense, namoro há oito anos com ela, assim, e ela sabe que... pode influenciar no final de semana o resultado de um jogo, assim. (...) Pra quem é muito fanático, ele condiciona um pouco sua vida àquilo, ao Fluminense, entendeu?

Em outra passagem, Vítor afirma que "a relação com o futebol, ela vai moldando um pouco o que você vai fazendo da vida". Isso se aplica, por exemplo, à necessidade de conciliar seus compromissos com a agenda de jogos do time:

Aí, isso influencia muito na minha vida, entendeu? (...) Tem os jogos que tão marcados e, e numa determinada semana eu vou meio que adaptando pra encaixar aqueles jogos. Aqueles jogos vão entrar, entendeu? E, pô... sábado eu tenho dois aniversários pra ir à tarde, mas, assim, o jogo do Fluminense é às 16 horas. Então, assim, minha prioridade é tentar ir ao jogo... tentar, não! Vou ao jogo, e o resto do fim de semana vai sendo encaixado dentro daquele, daquele horário, daquele calendário, assim. E era uma maneira um pouco... o futebol vai influenciando muito na sua vida, assim. 
Segundo Vítor, os efeitos de seu fanatismo pelo Fluminense são tão grandes que chegam mesmo a ser nocivos, atrapalhando sua vida em determinadas áreas, como os estudos e o trabalho:

As pessoas, do jeito que, que nós somos, assim, fanáticos, elas tentam melhorar em alguns momentos, porque isso atrapalha muita coisa, na vida... (...) Assim, eu levei muito tempo pra me formar na faculdade, um pouco porque eu fui contratado rápido no trabalho, e outra parte, assim, parcela de culpa pro Fluminense, entendeu? (...) já repeti várias matérias na faculdade. Assim, matéria quarta à noite, o campeonato, uma Copa do Brasil ou uma Libertadores, começa a engrenar, você vai matando aula toda quarta, enfim. (...) Mas, assim, influencia diretamente na minha vida. Atrapalha, é óbvio que atrapalha a minha vida, assim. Já fui prejudicado em muitas coisas, entendeu? No trabalho eu ficava desgastado, assim. (...) Na escola, atrapalhava, enfim. (...) eu repeti matérias já, outras matérias, na faculdade, não só por presença, mas porque, assim, você tá num momento como $2010 \ldots 2010$, sei lá, os últimos 10, 15 dias do campeonato, eu não conseguia fazer nada, absolutamente nada (...). Então, assim, é um influenciar muito na sua vida, que você passa $e$ você, $e$ vai te atrapalhando... (...) Cara, assim, já cheguei a ter que falar pra minha chefe que "eu não tô conseguindo trabalhar, vou ter que ficar quase enganando aqui". (...) Mas na semana do, um jogo como esse, assim, eu passava, assim, um dia inteiro vendo coisas do Fluminense, assim, vendo vídeo $e$ completamente inquieto, não conseguia ficar na minha cadeira, assim, levantava... assim, influencia muito, entendeu?

Ele destaca ainda o desgaste enfrentado no trabalho, principalmente quando precisa pedir permissão à sua chefe para faltar ou sair mais cedo, para poder assistir aos jogos de seu time:

(...) você acaba se desgastando. Eu cheguei pra minha chefe, (...) eu falei "pô, posso tirar um dia de férias", aí... 
como eu não gosto de inventar mentira, ela pergunta "ah, é pra algum, por algum problema pessoal?", eu falei "não", (...) "vou usar um dia de férias pra ver o jogo do Fluminense" (...). Ela fala "pô, você não devia falar que era pra jogo, você devia falar que era pra ir no, ir ao médico". Eu falo, cara... assim, não acho, é isso da prioridade pra vida... não acho que, assim, seja um motivo menos nobre, entendeu? Assim, acho que, assim, é um bom motivo. (...) $\mathrm{Eu}$ acho isso um motivo legítimo, entendeu? Se falar que, pô, você vai resolver problemas pessoais e eu vou ver um jogo do Fluminense, pra mim é um bom motivo, entendeu?

Como vemos, o fato de tratar os jogos de seu time como uma prioridade faz com que Vítor enfrente problemas em seu trabalho, pois nesse contexto, a intensidade da relação mantida com seu clube não é entendida como algo legítimo. Seu sentimento pelo clube teria assim um caráter "antissocial", $e$ provaria sua força justamente ao desafiar os valores e padrões de conduta que governam o senso comum. Para termos uma noção do impacto que o desempenho do Fluminense tem sobre seu comportamento, Vítor nos fala sobre o "trauma" vivenciado por ele com a perda da Copa Libertadores de 2008:

Eu tenho uma obsessão pela Libertadores, né? (...) Acho que todo tricolor tem, tem um trauma de 2008, assim. Eu tenho um amigo, que ele virou hipertenso a partir de 2008, assim... foi bizarro. (...) Ele virou hipertenso, ele desenvolveu hipertensão, ficou, sei lá, três anos, aí tomou remédio, assim, porque, cara... foi o maior choque que alguém pode, que um tricolor pode ter vivido, assim. (...) O Leandro, por exemplo, não vê nada da Libertadores, ele nunca viu nada... Se pegar, sei lá, o gol do Washington, ele nunca viu. Eu, eu consigo ver, mas, assim... isso de influenciar na vida, tem muito. Eu passei, cara, eu passei uns três meses, assim, tipo, mal, mal... mal mesmo, assim, mal pra vida, entendeu? (...) Alguém chamava pra fazer alguma coisa, minha namorada falava "pô, vamos sair", eu falava "não, vou ficar em casa", tipo... sábado à noite, 
assim, sabe? Assim, um mês e meio depois. Eu ficava, assim, pensando na vida, mal, mal, mal, mal... Isso é foda, cara. Foi um trauma forte. Assim, foi a memória mais triste, com certeza.

O entrevistado nos apresenta a perda da Libertadores como um "trauma", não só para ele, mas para todos os torcedores do Fluminense, destacando a dimensão coletiva dessa experiência. De fato, os demais torcedores do clube entrevistados para essa pesquisa também mencionaram a perda da Libertadores como um momento marcante em suas trajetórias. Isso aparece na entrevista de Jaime, que diz ter passado a madrugada chorando, paralisado dentro de seu carro, após o jogo. Vítor, por sua vez, menciona essa partida como sua memória mais triste enquanto torcedor, destacando o longo período de tristeza que se abateu sobre ele após a derrota. Ele nos fala também sobre Leandro, que teria passado um longo período sem nem mesmo conseguir falar sobre o assunto.

As memórias de Leandro sobre a perda da Libertadores merecem destaque, pois evidenciam o impacto do futebol sobre suas emoções e seu comportamento. Ele considera esse episódio como sua experiência "mais dolorosa" enquanto torcedor $e$ declara nunca ter sentido "um vazio tão grande" como aquele experimentado logo após a partida decisiva. Assim como Vítor, ele se refere a essa experiência como um "trauma" vivenciado nos planos pessoal e coletivo:

(...) mas a Libertadores ainda é um trauma. Tanto que, isso aí é uma opinião minha, o Fluminense, ele, o que atrapalha o Fluminense de ganhar a Libertadores é justamente esse trauma. (...) Foi, é um grande trauma, assim, é um negócio, um dos piores dias, momentos da minha vida, assim, de longe. (...) Eu... durante muito tempo, eu nem falava no assunto. E... mais do que isso, assim, as imagens da, da final... da Libertadores, eu fiquei, eu fui, eu nunca mais vi, assim, parar pra ver, num quis ver. 
O entrevistado também relata os efeitos desse episódio sobre sua experiência pessoal. Além de ter passado um longo período sem conseguir nem mesmo falar sobre o assunto, ou visualizar qualquer imagem relativa ao jogo, ele diz que se afastou dos estádios por cerca de um ano, chegando a enfrentar problemas no trabalho e em suas relações pessoais:

(...) engraçado que o Fluminense perdeu a Libertadores, eu comecei a trabalhar com jornalismo esportivo no globoesporte.com dois dias depois... não aguentei. Pedi demissão três meses depois, era tortura demais pra mim. (...) tem outras questões também. Questão de ganhar mal, ser explorado, perspectiva profissional, mas assim, a derrota tornou aquela experiência insuportável. Porque foi uma experiência muito dolorosa e que você tenta meio que fugir e, aquilo, eu praticamente tava respirando aquela porra, aquilo no meu trabalho o dia inteiro. (...) Então, era o dia inteiro falando daquilo, vendo aquilo... É, foi... horrível.

(...) eu fiquei um ano sem conseguir pisar no estádio... sem ver jogo. E o Fluminense entrou num buraco muito grande também. E... mas, o mais louco de tudo é que, aí a minha vida foi piorando, aí no ano seguinte o Fluminense... aí a coisa degringolou. Aí no Globo Esporte, eu não aguentei trabalhar, pedi demissão, fiquei desempregado. Aí daqui a pouco, aí tava sem dinheiro, desempregado, meu relacionamento, com a minha namorada, de quatro anos, foi pro vinagre também.

O clube é também apontado como o principal fundamento para a constituição de sua "identidade":

A minha identidade é pautada, enquanto, em cima do Fluminense, assim (...) a minha identidade primordial é de tricolor. Então, assim, antes de me enxergar enquanto brasileiro, enquanto qualquer coisa, enquanto homem, enquanto minha religião, (...) eu sou tricolor. Se eu for me definir, eu sou um tricolor. Eu não sou um brasileiro, eu sou um tricolor. Me define, a imagem que eu tenho do tricolor, 
enfim, até a imagem que eu tenho idealizada do que é o tricolor é o que eu tento ser... e, enfim, eu acho que eu sou o Fluminense e o Fluminense sou eu. Acho que o clube, assim, o time, aqueles caras lá, 22 jogando, eles não são o clube, o clube é a torcida... é a cultura, é a história, enfim. $\mathrm{E}$ sou eu, somos nós, é o que a gente constrói. É um... é algo vivo, né? (...) Mas é isso, é a minha principal identidade, eu me vejo como tricolor.

Ao apontar o Fluminense como base para a formação de sua "principal identidade", o entrevistado procura definir o tipo de relação mantida com o clube, bem como a importância dessa relação. Apesar do impacto que o futebol tem sobre sua vida, Leandro não se considera, contudo, um torcedor "fanático", mas sim, um apaixonado:

(...) eu não me considero fanático, não, acho... talvez, apaixonado seja mais... (...) é porque eu não acho que isso seja, porque eu não acho que isso tenha um impacto nocivo na minha vida. Já teve, mas hoje em dia é mais tranquilo. (...) Eu acho que... fanatismo, se isso prejudicasse de alguma forma, se me fizesse fazer coisas que eu não faria e... não é o caso.

A maioria dos entrevistados recusou a noção de "fanatismo" como algo negativo, em parte pela associação desse termo ao comportamento violento frequentemente vinculado pela opinião pública às torcidas organizadas. Por outro lado, podemos compreender a recusa à noção de "fanatismo" pelo modo como a relação de tipo carismático é concebida na modernidade ocidental. Num estudo sobre as cartas de amor escritas por fãs a seus ídolos, Coelho (1999) questiona a preferência de seus pesquisados pela noção de amor, e não de carisma, para a caracterização dessa relação. Baseando-se em Lindholm (1993), ela indica o carisma como a relação de um grupo de seguidores membros de uma igreja, fãs de uma banda ou torcedores de um clube - com seu ídolo. Numa relação desse tipo, os seguidores 
abrem mão de sua singularidade e passam a fazer parte de uma multidão indiferenciada, na qual a única individualidade que se sobressai é a do ídolo.

$\mathrm{Na}$ modernidade ocidental, porém, a individualidade é erigida como um valor fundamental. Isso torna depreciável o lugar do seguidor em uma relação de tipo carismático, como discute Jenson (1992) ao apontar a caracterização dos fãs como dividida em dois estereótipos: a "massa histérica" e o solitário patológico. Por isso, ao invés de carisma ou "fanatismo", os torcedores assim como os fãs na relação com seus ídolos - afirmam sentir amor e paixão por seus clubes, resgatando a si mesmos (a exemplo dos fãs analisados por Coelho) enquanto sujeitos valorizados porque dotados da singularidade que caracteriza os apaixonados.

Em conformidade com isso, Roberto recusa também a noção de fanatismo, interpretando-a como algo negativo. Ele se apresenta como um torcedor "equilibradamente apaixonado", conciliando a desmesura da paixão com a lógica de controle que seria um atributo de masculinidade, numa síntese peculiar:

Eu acho que a palavra "fanático" tem uma carga negativa, sabe, cara? Acho que ser fanático, sempre tem uma coisa meio "ah, fulano é fanático", ou seja, que o cara é maluco, entendeu? (...) Então, eu me considero um apaixonado. Eu sou equilibradamente apaixonado pelo futebol $e$ pelo Flamengo, entendeu? Não me considero fanático. (...) Cara, eu acho que eu sinto uma paixão. Eu sinto uma paixão, isso aí... ah, é uma paixão, é um sentimento diferente, é um sentimento de, de... (...) é uma sensação de pertencimento, sabe, assim? Ou seja, que eu faço parte de uma, de uma, de uma legião e tal, e de uma torcida e, sim, me considero um apaixonado pelo clube, né, cara? Acho até que o... acho que o único verdadeiro amor de um homem é pelo clube, cara. Eu acho, porque... se eu tomar de 6 amanhã do Goiás, eu na semana que vem vou estar vendo de novo o jogo do Flamengo, né? Agora, num sei se, num sei se em todos os aspectos da vida, você pode dizer a mesma coisa, né? Se a tua mulher te trai... num sei se você 
vai voltar a ficar com ela no dia seguinte. Mas se o Flamengo toma de 6 do Vasco no próximo clássico, eu vou ficar puto, vou ficar triste, mas depois, no outro jogo é... é ser casado de novo.

Roberto se considera, portanto, um torcedor "equilibradamente apaixonado" pelo Flamengo. Esse sentimento envolve, mais uma vez, a noção de pertencimento a uma determinada "comunidade de sentimentos", formada pelos torcedores do clube. $\mathrm{O}$ entrevistado acredita que a ligação afetiva do torcedor com seu time representaria o "único verdadeiro amor de um homem", devido ao caráter incondicional desse sentimento. Segundo Roberto, somente nesse tipo de relação, a fidelidade que acompanha o amor romântico se concretizaria efetivamente, pois um torcedor, idealmente, nunca abandona seu time - o que não se observaria nem mesmo no âmbito das relações conjugais.

Nos discursos de amor e paixão dos entrevistados, encontramos a idealização de uma união perfeita entre as dimensões de intensidade e de estabilidade, originando-se esta última da fidelidade devida pelo torcedor ao clube amado. Como afirma Simmel (1964), a fidelidade é um sentimento sociologicamente orientado, que possibilita a continuidade de uma relação, mesmo quando as motivações que lhe deram origem já não se encontram mais presentes. Isso pode ser observado no depoimento abaixo:

Cara, eu gosto do Flamengo, eu sou flamenguista, eu acho que isso num... (...) não só o Flamengo, acho que qualquer pessoa, né, que eu acho que fala assim "ah, eu não sou mais um time, agora eu vou ser outro". Porra, uma pessoa dessa, cara, eu acho que ela não merece nem, sei lá, ir pro estádio, sabe? Ou falar qualquer coisa, porque eu acho que o time, você... tudo bem, você não tá ganhando nada com isso? Pô, não, mas é aquela coisa, é... isso acaba te remetendo a uma série de lembranças, coisas boas, coisas ruins, né? (...) Eu acho que a relação minha com, com o 
Flamengo hoje é justamente essa, assim, porque... aquela coisa, você, você cresceu naquele meio né, cara, então você acaba acompanhando. (...) É lembrança, é crescimento, o cara lembra quando ele era, desde pequeno... num vai mudar depois, entendeu? Então, acho que a minha relação com o Flamengo é justamente essa. Num é questão de, "ah, que eu acho que o time é bom pra cacete, eu acho que o time vai pra frente". Pô, eu acho que é algo além disso, assim (Fernando).

No contexto do futebol, a fidelidade se apresenta como um valor fundamental. Segundo Damo (2002), esse sentimento é responsável por conferir estabilidade ao futebol enquanto sistema simbólico. Se os torcedores pudessem mudar de time a qualquer momento, não seria possível a constituição dos clubes como "comunidades de sentimentos", nem haveria os sistemas de relações organizados em torno deles. Em última instância, não haveria torcedores, mas apenas espectadores. Assim, o torcedor que muda de time recebe a alcunha de "vira-casaca" e passa a ser tratado com desconfiança entre seus pares. Para Vítor, a mudança de time, a partir de certa idade, não se encontraria nem mesmo no horizonte de possibilidades de um torcedor:

(...) o "virar casaca" existe até um certo momento... até 10, 12 anos. Não passa pela cabeça de ninguém, alguém com 23 anos de idade mudar de time, né? Não é algo real, a partir do momento que você escolhe e passou de 13, 14 anos, eu acho que é muito improvável que alguém mude de time.

Tendo em vista a importância da fidelidade na relação do torcedor com seu clube, a mudança de time pode acarretar sanções por parte dos outros torcedores. Nesse sentido, Ademir destaca sua fidelidade ao Flamengo e menciona o tratamento dado a um amigo que mudou de time durante a juventude: 
Eu tenho um amigo, ele tá lá nos seus 47, 48 anos, entendeu? Ele era Flamengo doente, de ir ao Maracanã, bandeira, ele ia ao Maracanã com a gente, essa coisa toda, torcia e tal... E nessa era mesmo, Zico e Dinamite, é... aconteceu que o Flamengo perdeu um título pro Vasco. É o único sujeito até hoje que eu conheço na história: ele passou a ser Vasco daquele dia pra cá e é até hoje vascaíno. Então, toda vez que a gente tá conversando, e ele começa a falar de futebol, eu dou uma sacaneada nele e proîbo: "você não pode falar de futebol, que tu é proibido!".

Nessa história, a mudança de time se mostra ainda mais grave por ter ocorrido entre arquirrivais. A importância da fidelidade também aparece nos discursos de torcedores cujos times enfrentaram a experiência do rebaixamento, situação vivenciada como uma "humilhação", por colocar em xeque o pertencimento simbólico de um clube à elite do futebol. Esse é o caso de Jaime, que afirma ter acompanhado o Fluminense em todos os jogos da terceira divisão. Nesse período, sua relação com o clube teria se tornado ainda mais intensa:

Fui ao Maracanã em obras (...). Eu vi todos os jogos do Fluminense na terceira divisão. (...) No Rio de Janeiro, eu vi todos, o Maracanã em obras, a gente ficou nas cadeiras, onde eram as cadeiras. (...) Eu fui a todos os jogos da terceira divisão, todos! (...) A terceira divisão mexeu comigo. Eu enlouqueci com a terceira divisão... com a segunda divisão...

Wagner também afirma ter acompanhado todos os jogos de seu time na segunda divisão:

Acompanhei, todos os jogos que eu podia, eu ia a São Januário. Esse ano, eu até pude, até acompanhei mais, ia a São Januário... botequim, entendeu? Em casa... terça, sexta, é... acompanhei mais o Vasco. Fui com o Vasco pra segunda e voltei. 
Como podemos observar, Jaime e Wagner apontam, novamente, o torcedor como o "locus da emoção" no futebol, destacando o engajamento afetivo que se encontraria na base da relação do torcedor com seu clube. Ao longo da pesquisa, nossos entrevistados declararam sentir amor, paixão e fidelidade por seus clubes, enquadrando-se nos discursos do amor-paixão ou do amor romântico que, conforme vimos rastreando nos relatos, orienta as experiências afetivas dos torcedores de futebol. O que queremos destacar, nesse ponto, é a associação entre a masculinidade, no contexto do futebol, com uma sentimentalidade culturalmente compreendida como um traço típico do comportamento feminino.

Por estarem associados à feminilidade, os sentimentos são entendidos como sinais de fraqueza e descontrole, que devem ser evitados com vistas à manutenção de uma conduta genuinamente masculina (Lutz, 1988). O universo do futebol, contudo, complexifica esse modelo, como sugere a recorrência de relatos sobre o "choro masculino".

Na cultura ocidental, a emotividade é compreendida como um atributo de feminilidade, devendo ser evitada pelos homens para a sustentação simbólica de sua virilidade. Nesse sentido, os homens não devem sentir ou, pelo menos, não devem demonstrar publicamente o que sentem, pois isso poderia comprometer sua masculinidade. À luz dessa "regra de sentimento" (Hochschild, 2013), derramar lágrimas, sobretudo em público, é interdito aos homens, na medida em que o choro é culturalmente compreendido como a principal forma de expressão dos sentimentos.

Todavia, ao longo das entrevistas realizadas para esta pesquisa, diversos torcedores relataram momentos de choro desencadeados pelas emoções vivenciadas no futebol. Esse é o caso de Wagner, que ao ser questionado se já havia chorado alguma vez pelo Vasco, respondeu: 
Quando o time é campeão, a emoção vem mais forte, né, cara? Quando teu time é campeão, você... é aquilo que eu te falo, você lá no campo, você tem, sente o calor da torcida, o... calor da torcida, o calor da emoção de você tá vendo, aí você, você, você assim, a tua adrenalina, é... você, mexe mais com você.

O entrevistado afirma que quando seu time é campeão, "a emoção vem mais forte" - ou seja, ele chora. Sintomática da força da interdição do choro é a forma eufemística de admiti-lo: a "emoção vem mais forte", como algo de fora que o subjuga, produzido pelo contato com a "comunidade de sentimentos", $e$ sem o reconhecimento explícito do choro, apesar da diretividade da formulação da pergunta. Esse episódio de choro é representado como um momento de descontrole, ocasionado pela intensidade das emoções vivenciadas em decorrência da conquista de um título. Roberto também relata um episódio semelhante:

Chorei numa, numa Copa do Brasil. Chorei num Flamengo e Palmeiras, Copa do Brasil. (...) E aí foi lá no Parque Antártica jogar contra o Palmeiras... fez 2 a 1 em cima do Palmeiras. Porra, 2 a 1, com 35 minutos do segundo tempo, o Flamengo precisava tomar três gols pra ser eliminado... Tomou! (...) Foi, foi, foi bem triste. Eu acho que foi a única vez que eu chorei, assim, chorar de... de lágrima correr, assim.

Fernando relembra um jogo em que "chorou de raiva" após a perda de um título:

Cara, chorei de raiva. Num foi de, de, de tristeza não, foi de raiva, de tão puto que eu tava. Foi no Flamengo e Grêmio, final da Copa do Brasil, 97, gol do Lúcio. Flamengo ganhando de 2 a 1 , os caras meteram 2 a 2, aos 40 e varada já, assim... Aí o Flamengo perdeu o título. Pô, fiquei desesperado! 
O entrevistado salienta que seu choro foi motivado pelo sentimento de raiva, e não de tristeza, o que pode ser entendido como uma tentativa de legitimar suas lágrimas. Afinal, a raiva é uma das poucas emoções culturalmente associadas ao comportamento masculino, sendo relacionada à violência e à agressividade (Jimeno Santoyo, 2004). O choro de tristeza, por sua vez, permaneceria simbolicamente ligado à fragilidade típica da sensibilidade feminina. No depoimento de Vítor também podemos observar a particularidade do choro masculino no contexto do futebol:

Eu não choro tanto. Assim, eu tenho esse problema, assim, que eu choro pouco. Não que eu não fique emocionado, mas assim, eu tenho... eu passo muito tempo sem chorar, entendeu? Sou até um pouco, porque eu sou racional demais com, com sentimentos, entendeu? Assim, eu tenho um pouco disso pra chorar, mas... eu chorei, assim, duas vezes, assim. Nem foi exatamente na hora. Na Copa do Brasil foi, mas na Libertadores... na Libertadores, foi um pouco esperando, um pouco durante a noite, entendeu? Assim, um pouco saindo do Maracanã e um pouco ao longo da noite.

Leandro, que também torce pelo Fluminense, foi mais categórico ao falar sobre suas expressões emotivas pelo clube:

Cara, se quiser chorar, é o Fluminense. Pra me fazer chorar fácil, é o Fluminense. Mas é engraçado, eu não choro pelo Fluminense de tristeza, assim, eu nunca chorei em nenhum rebaixamento, nem chorei quando o Fluminense perdeu a Libertadores, em nenhum momento, nem depois, assim. $\mathrm{E}$ vou, que o Fluminense perdeu a Libertadores, eu comecei a ter, eu tive problema de insônia mesmo, eu... até hoje eu durmo mal. E eu comecei a ter problema de insônia depois que perdeu a Libertadores. Mas eu nunca chorei por derrota. E, mas eu choro quando o Fluminense ganha e... quando é campeão, eu choro. Fluminense, qualquer título do Fluminense, eu vou chorar que nem uma criança, 
entendeu? E... sei lá, certos vídeos, eu choro... (...) É nesse nível a coisa, entendeu? Me emociono mesmo.

De modo semelhante, Jaime menciona diversas ocasiões em que teria chorado por seu "clube do coração":

Eu tenho um livro chamado "Fla x Flu - E as multidões despertaram". São artigos do Nélson sobre o Flamengo, e do, e do, e do Mário sobre o Fluminense. São textos de chorar, chorar... O primeiro texto é do Mário, sobre o Fluminense, eu, quando li a primeira vez o livro, eu não consegui ler até o fim, eu chorava copiosamente, assim, um negócio impressionante.

A destacar no depoimento de Jaime, seus relatos de choro não estão necessariamente ligados aos momentos de extrema alegria e tristeza vivenciados no futebol, como aqueles motivados pela conquista de títulos ou por uma grande derrota. Suas lágrimas mostram-se frequentes em sua experiência como torcedor, envolvendo situações triviais, como a leitura de um livro, ou jogos sem grande relevância para a classificação de seu time numa competição:

Eu vi um Fluminense e Santos que eu chorei demais, tava 2 a 0 Santos, 43 minutos, (...) o César foi lá, fez dois gols de cabeça. Esse dia eu passei mal! (...) Eu, eu não desmaiei nesse jogo por acaso, eu chorei, mas eu chorei tanto nesse jogo, assim, de emoção... (...) Chorei, eu chorava desesperadamente... de emoção. Foi um 2 a 2. Então, é um negócio que mexeu comigo. Você diz assim "mas o que que valia?" Nada... valia não perder pro Santos.

Segundo Vincent-Buffault (1988), as lágrimas simbolizam o descontrole do indivíduo e o rompimento da barreira simbólica que separa a interioridade do sujeito e o meio social externo. Idealmente, tudo se passa como se sentíssemos uma emoção muito forte e não conseguíssemos nos conter, deixando-nos então 
revelar pelo derramamento de lágrimas. O choro não consiste, todavia, numa mera reação fisiológica, nem tampouco num ato puramente espontâneo. Como Mauss (1980) já havia assinalado, toda expressão de sentimentos tem um caráter coletivo $e$ obrigatório, constituindo uma espécie de linguagem, que permite a comunicação social de estados subjetivos.

As emoções e suas formas de expressão se organizam de acordo com normas sociais específicas, que podem variar no tempo e no espaço. Nesse sentido, Vincent-Buffault (1988) identifica um momento de redefinição dos padrões emotivos da cultura ocidental com o advento da modernidade. Seguindo o diagnóstico de Elias (1993), ela afirma que esse período teria sido marcado pelo avanço de um processo civilizador baseado fundamentalmente na valorização social da contenção emotiva, o que teria levado a um escasseamento histórico das lágrimas. Embora esse padrão se aplicasse a todos, a autora destaca sua maior difusão entre os homens modernos, enquanto a feminilidade teria permanecido associada a uma emotividade descontrolada e excessiva. Ou seja, a contenção emotiva e, em particular, das lágrimas, seria um traço da modernidade como um todo, mas, sobretudo, do modelo de masculinidade erigido nesse período. Parafraseando Mauss, o padrão da emotividade masculina consistiria, portanto, numa "não-expressão" obrigatória dos sentimentos.

Mas o choro dos entrevistados surge, nesses relatos, como um atestado de seu amor, sua paixão, sua fidelidade por seus clubes. O choro, assim, é aqui uma virtude, pois não atesta fragilidade ou vulnerabilidade, mas sim potência emocional, uma potência diretamente relacionada com sua masculinidade.

Outros estudos devotados à análise das emoções associadas à masculinidade fizeram já descobertas etnográficas que mostraram que a identidade masculina pode, em determinados contextos, estar fortemente ancorada na valorização das emoções, em particular do amor. Simoni (2015), em artigo publicado como parte do dossiê mencionado na introdução desse artigo, discute o modo como homens cubanos envolvidos em relacionamentos 
amorosos com turistas estrangeiras encenam concepções diversas de masculinidade, sintetizadas nas imagens arquetípicas da "máquina sexual", do "provedor" e do "amante romântico". Eventualmente contraditórias e, por isso mesmo, deles demandando esforços de síntese e conciliação, essas três imagens permitem "diferentes possibilidades relacionais e expressões de masculinidade" (Simoni, 2015:408, tradução nossa). De particular interesse para nosso argumento é o lugar do amor nessa construção da masculinidade:

\begin{abstract}
O que era extremamente importante na preservação desta configuração moral do amor era que essas responsabilidades $e$ obrigações fossem vivenciadas não como aquilo que motiva o amor, mas como um resultado derivado desse sentimento. (...) Embora possamos objetar que essa é uma idealização bastante abstrata e pura do amor romântico, era a ela que muitos homens cubanos com quem convivi pareciam aspirar, ou ao menos apontar como algo que podiam e queriam alcançar. (...) o amor aqui parecia colocar em cena a noção de seres humanos igualmente sensíveis, bem como uma configuração de poder menos polarizada em torno do gênero (Simoni, 2015:407, tradução nossa).
\end{abstract}

Essa associação da masculinidade ao amor pode aparecer, em outras situações etnográficas, até mesmo em articulação com o descontrole. É o caso da análise realizada por Giacomini (2011) sobre o consumo da música "brega" na Feira de São Cristóvão do Rio de Janeiro. Giacomini mostra que o "brega" apresenta uma configuração peculiar: trata-se de um estilo musical em que cantores homens expressam suas dores amorosas para uma plateia feminina, naquilo a que a autora se refere como um "transbordamento" emocional. Encontramos aí mulheres "consumindo" o descontrole emocional masculino, provocado pelo sofrimento causado pelo abandono ou pela traição. A autora aponta a natureza "destoante" do mundo "brega" no que diz respeito às relações entre gênero e emoção: "nele encontram-se invertidos os lugares polares ocupados pelos gêneros. É o homem 
e não a mulher que, de forma conspícua, ocupa o núcleo ou centro para expressar seus sentimentos e emoções" (Giacomini, 2011:41).

Essa inversão faz com que o caso analisado por Giacomini represente uma contribuição significativa para o campo da Antropologia das Emoções, conforme discutimos em outro lugar:

Essa forma particular de articular gênero e emoção, em que mulheres "consomem" narrativas de homens falando sobre suas dores na experiência amorosa de forma incontida, torna o estudo do caso da música 'brega' de enorme relevância para o campo da antropologia das emoções, uma vez que realiza um duplo rompimento com a forma "euroamericana" de conexão entre ambos, tal como descrita por Lutz: aqui, a emoção é masculina $e$ descontrolada, sendo este, aparentemente, o maior atrativo desse estilo musical para as mulheres que o "consomem" (Coelho; Rezende, 2011).

O caso etnográfico aqui discutido realiza um movimento que, se por um lado, guarda uma semelhança fundamental com o mundo brega em sua natureza - a valorização do descontrole emocional masculino -, por outro nos permite dar dois passos à frente. Em primeiro lugar, esses homens transtornados, que choram e desmaiam por amor, não têm como objeto amoroso, como causa do seu desatino, uma mulher, mas sim um clube - ao qual juram fidelidade e amor eterno, contrastando com o valor dado à infidelidade e à "predação sexual", como sinais de virilidade, nas relações com as mulheres (Vale de Almeida, 1995). E, em segundo lugar, suas dores são compartilhadas, são dores coletivas que atestam um pertencimento a uma "comunidade de sentimentos", estando assim distantes daquele amor que singulariza, como nas histórias arquetípicas da forma moderna de amar (Benzaquen de Araújo; Viveiros de Castro, 1977).

Não por acaso, Lamartine Babo recheou os hinos dos clubes cariocas de imagens amorosas, como nos hinos do Flamengo ("Na regata, ele me mata, me maltrata, me arrebata, 
que emoção no coração!"), do Fluminense ("O Fluminense me domina, eu tenho amor ao tricolor!") ou, de forma especialmente enfática, do América:

Hei de torcer, torcer, torcer

Hei de torcer até morrer, morrer, morrer

Pois a torcida americana é toda assim

A começar por mim

A cor do pavilhão é a cor do nosso coração

Em nossos dias de emoção

Toda torcida cantará esta canção

\section{Considerações finais}

Homens que choram e desmaiam por amor a um clube de futebol: qual o lugar das emoções na construção dessa forma de masculinidade?

O futebol se apresenta, aqui, como um contexto excepcional em que o imperativo da contenção emotiva é subvertido e a expressão de sentimentos passa a ser conciliada com os ideais hegemônicos de masculinidade. Essa natureza descontrolada de um amor compartilhado por um clube no universo masculino do futebol pode ser tomada como estratégia de construção/afirmação da masculinidade: os homens aqui choram, desmaiam, passam mal, deprimem e não conseguem trabalhar por causa das (des)venturas de seu time.

Reside, aqui, o interesse maior desse caso etnográfico para o campo da Antropologia das Emoções. Pois, como vimos acima, a literatura aponta para uma recorrência, na ciência, na arte, e mesmo no senso comum das sociedades ocidentais modernas, de uma associação entre a feminilidade e o descontrole emocional, associação essa que guardaria estreita relação com a valorização da masculinidade em sua articulação com a dominação. A masculinidade, em suas formas hegemônicas, seria a guardiã da razão e do controle emocional, e por isso reservatório de confiabilidade, estabilidade e, em decorrência disso, poder. $\mathrm{O}$ poder seria, assim, o termo que viria completar uma tríade 
temática central para o campo da Antropologia das Emoções: gênero, controle emocional e poder (Lutz, 1990).

$\mathrm{O}$ caso etnográfico aqui tratado coloca em xeque a inevitabilidade tanto das associações entre a feminilidade e o descontrole emocional quanto da desvalorização desse descontrole. Pois esse descontrole, se associado à masculinidade, se vivenciado coletivamente e se dirigido a um clube, pode aqui receber aquela valência positiva associada, em tantos outros contextos, ao seu oposto: a "fria" razão e o controle caracterizados como atributos da masculinidade.

O descontrole emocional, aqui, é atestado de virilidade, estratégia de afirmação da masculinidade. Pois, não são justamente esses arroubos emocionais que, nesses relatos, atestam o compromisso de seus torcedores com seus times e, por tabela (com o perdão do trocadilho), com sua masculinidade?

\section{Referências bibliográficas}

ABU-LUGHOD, Lila. Veiled sentiments: honour and poetry in a Bedouin society. Berkeley, University of California Press, 1986.

ABU-LUGHOD, Lila; LUTZ, Catherine. Introduction. In: ABU-LUGHOD, Lila; LUTZ, Catherine. Language and the politics of emotion: studies in emotion and social interaction. New York, Cambridge University Press, 1990, pp. 24-45.

ADELMAN, Miriam. As mulheres no mundo equestre: forjando corporalidades e subjetividades "diferentes". Estudos Feministas, v. 19, n. 3, 2011, pp. 931-953.

ANDERSON, Benedict. Comunidades imaginadas: reflexões sobre a origem $e$ a difusão do nacionalismo. São Paulo, Companhia das letras, 2008.

BANDEIRA, Gustavo. Amor e masculinidade nos estádios de futebol. Esporte e Sociedade, v. 19, 2012, pp. 1-26.

BENZAQuen de ARAúJo, Ricardo; Viveiros de CASTRO, Eduardo. Romeu e Julieta e a origem do Estado. In: VeLHO, Gilberto (org.). Arte e Sociedade. Rio de Janeiro, Zahar, 1977, pp. 130-169. 
COElHO, Maria Claudia. A experiência da fama: individualismo e comunicação de massa. Rio de Janeiro, Fundação Getúlio Vargas, 1999.

CoElHO, Maria Claudia; Rezende, Claudia Barcellos. Introdução - O campo da antropologia das emoções. In: COELHO, Maria Claudia; Rezende, Claudia Barcellos (org.). Cultura e sentimentos: ensaios em antropologia das emoções. Rio de Janeiro, Contra Capa, 2011. p. 7 26.

DAMO, Arlei Sander. Futebol e identidade social: uma leitura antropológica das rivalidades entre torcedores e clubes. Porto Alegre, Editora da UFRGS, 2002.

ELIAS, Norbert. O processo civilizador. formação do Estado e civilização. Rio de Janeiro, Jorge Zahar, vol. 2, 1993.

Elias, Norbert; DunNing, Eric. Em busca da excitação. Lisboa, Difel, 1992.

GIACOMINI, Sonia Maria. Emoção "brega" e relações de gênero na feira de São Cristóvão: corações, corpos e mentes em transbordamento emocional. In: COELHO, Maria Claudia; REZENDE, Claudia Barcellos (orgs.). Cultura e sentimentos: ensaios em antropologia das emoções. Rio de Janeiro, Contra Capa/FAPERJ, 2011, pp. 27-43.

GIDDENS, Anthony. A transformação da intimidade: sexualidade, amor e erotismo nas sociedades modernas. São Paulo, Editora UNESP, 1993.

HOCHSCHILD, Arlie. Trabalho emocional, regras de sentimento e estrutura social. In: COELHO, Maria Claudia (org.). Estudos sobre interação: textos escolhidos. Rio de Janeiro, EdUerj, 2013, pp. 169-209.

JENSON, Joli. Fandom as pathology: the consequences of characterization. In: LEWIS, Lisa. The adoring audience: fan culture and popular media. London, Routledge, 1992, pp. 9-29.

JiMENO SANTOYO, Myriam. Crimen pasional: contribución a una antropología de las emociones. Bogotá, Universidad Nacional de Colombia, 2004.

LINDHOLM, Charles. Carisma. Rio de Janeiro, Jorge Zahar, 1993. 
LUTZ, Catherine. Unnatural emotions: everyday sentiments on a Micronesian atoll and their challenge to Western theory. Chicago, University of Chicago Press, 1988.

LUTZ, Catherine (1990). "Engendered emotion: gender, power, and the rhetoric of emotional control in American discourse". In: LUTZ, Catherine; ABU-LuGHOD, Lila (orgs.) Language and the Politics of Emotion: studies in emotion and social interaction. Cambridge: Cambridge University Press, pp. 69-91.

LUTZ, Catherine; WHITE, Geoffrey. The anthropology of emotions. Annual Review of Anthropology, v. 15, 1986, pp. 405-436.

MAUSS, Marcel. A expressão obrigatória dos sentimentos. In: FIGUEIRA, Sérvulo Augusto (org.). Psicanálise e ciências sociais. Rio de Janeiro, Francisco Alves, 1980, pp. 56-63.

PISCITELli, Adriana; SimONI, Valerio. Masculinities in times of uncertainty and change: introduction. Etnográfica, v. 19, n. 2, 2015, pp. 293-299.

RIOS, Fábio Daniel. Futebol, masculinidade e emoção: memórias apaixonadas de torcedores. Dissertação de mestrado, Ciências Sociais, UERJ, 2014.

ROJO, Luiz Fernando. A produção do gênero no hipismo à luz dos discursos sobre as emoções. In: COELHO, Maria Claudia; REZENDE, Cláudia Barcellos (orgs.). Cultura e sentimentos: ensaios em antropologia das emoções. Rio de Janeiro, Contra Capa/FAPERJ, 2011, pp. 45-61.

ROSALDO, Michele. Toward an anthropology of self and feeling. In: SHWEDER, Richard; LEVINE, Robert (orgs.). Culture theory. essays on mind, self, and emotion. Cambridge, Cambridge University Press, 1984, pp. 137-157.

SIMMEL, Georg. Faithfulness and gratitude. In: WoLFF, Kurt (org.). The sociology of Georg Simmel. New York, Free Press, 1964, pp. 379395.

SimMEL, Georg. O problema da Sociologia. In: MORAES FILHO, Evaristo (org.). Simmel: Sociologia. São Paulo, Ática, 1983, p.59-86.

SIMONI, Valerio. Breadwinners, sex machines and romantic lovers: entangling masculinities, moralities, and pragmatic concerns in touristic Cuba. Etnográfica, vol. 19, n. 2, 2015, pp.389-411. 
VAle DE AlmeIDA, Miguel. Senhores de si: uma interpretação antropológica da masculinidade. Lisboa, Fim do Século, 1995.

VInCENT-Buffault, Anne. História das lágrimas: séculos XVIII-XIX. Rio de Janeiro, Paz e Terra, 1988. 